\title{
The Influence Mechanism and Contingency Thinking of Subsidiaries' Green Governance Within the Framework of Group - Based on Disclosure of Environmental and Sustainable Development Information
}

\author{
Kecheng Zhang ${ }^{1}$, Guiyu Bai ${ }^{2}$, Delin Meng ${ }^{3}$, Peng $\mathrm{Xu}^{3,4 *}$ \\ ${ }^{1}$ School of Business Administration,Shandong Women's University, No. 2399, Daxue Road, 250300, Jinan,China \\ ${ }^{2}$ Business School, University of Jinan, No.13 Shungeng Road,250002, Jinan, China \\ ${ }^{3}$ School of Business Administration, Shandong University of Finance and Economics, \\ No.7366 East Erhuan Road, 250014, Jinan, China \\ ${ }^{4}$ Center for Corporate Governance, Shandong University of Finance and Economics, \\ No.7366 East Erhuan Road, 250014, Jinan, China
}

Received: 20 April 2021

Accepted: 24 October 2021

\begin{abstract}
Listed companies in China's Shanghai and Shenzhen stock markets are selected as research objects, the influence of executives' synergy allocation of parent and subsidiary companies on green governance level of subsidiaries is investigated. Using the 3100 sets of sample data formed from 2014 to 2017, then tested the hypothesis empirically through multiple regression analysis using STATA 15.1. The results show: (1) Executives' synergy allocation of parent and subsidiary companies has a positive impact on green governance level of subsidiaries; (2) The moderating effect of equity checks and balances and the property rights nature of enterprise groups is verified, the specific performance is: the lower the equity checks and balances, the stronger the positive influence of the executives' synergy allocation of parent and subsidiary companies on green governance level of subsidiaries; (3) Compared with state-owned enterprise groups, the influence of executives' synergy allocation of parent and subsidiary companies has a stronger impact on green governance level of subsidiaries in private enterprise groups; (4) Further analysis shows that part of the reason for the positive impact of executives' synergy allocation in parentsubsidiary companies on the green governance level of the subsidiaries is that executives' synergy allocation has alleviated the first type of agency costs to some extent.
\end{abstract}

Keywords: executives' synergy allocation; green governance, equity checks and balances, property rights nature, agency costs

*e-mail: 20157684@sdufe.edu.cn 


\section{Introduction}

From the perspective of economic development, China has entered a new era of slowing down the growth rate, changing from quantity to quality and optimizing the structure, under the background of "coordination of environmental protection and economic and social development", higher requirements are put forward for enterprises to correctly establish the concept of environmental protection and actively carry out corporate green governance [1]. Green development not only requires the government to describe the vision of development and build a system to guide environmental governance, but also requires enterprises have an inescapable responsibility for ecological civilization and sustainable economic development. Green corporate governance is well adapted to the concept of sustainable development of enterprises. The implementation of green governance can not only promote the green development and green transformation of enterprises, but also promote enterprises to build a global view of green governance, which is conducive to the fairness, ecology, and sustainability of global economic development $[2,3]$. The implementation of green governance is also of great significance helpful for developing countries to gain international discourse rights and promote the construction of human community of common destiny [4].

According to stakeholder theory, listed companies should not only focus on the accumulation of shareholders' wealth or on short-term financial performance, but also balance the requirements of various stakeholders to achieve the ultimate value creation while creating social benefits [5-6]. Green corporate governance advocates and promotes the establishment of a public equal, voluntary, and cooperative relationship between listed companies, government, and social organizations, and coincides with the concept of mutual assistance and cooperation among stakeholders of companies [7]. Implementation of green corporate governance can show the public enthusiasm of fulfilling social responsibility, and help to enhance the social reputation and external legitimacy of listed companies [8-10]. At the same time, implementation of green corporate governance can also meet the reasonable demands of stakeholders for the company's business decision-making, take stakeholders as the strategic resources, and enhance the competitive advantage of the enterprise. Therefore, for modern enterprises, how to improve the level of green governance through internal governance design, seize the opportunity and grasp the initiative of future competition has become an important issue of common concern to the theoretical and practical circles [11-12].

In view of the positive significance of green governance, at present, the academic circles have made a lot of analysis on the willingness and status of enterprises to implement green governance from the aspects of disclosure of green environmental information and fulfilling environmental responsibility. Firstly, environmental information disclosure: Empirical research on Chinese enterprises of $\mathrm{Li}$ et al. (2016) shows that there is a negative correlation between corporate environmental information disclosure and financial performance [13]. Stefano et al. (2015) believe that companies with better environmental performance will actively disclose environmental information in order to gain better benefits from stakeholders who prefer "good news" [14]. Short-selling mechanism is thought as an external governance mechanism can improve the efficiency of information transmission, enhance the motivation of large shareholders' supervision and management, and thus have a positive impact on the quality of enterprise environmental information disclosure [15]. Secondly, environmental responsibility: Liu et al. (2017) found that in order to seek their own sustainable development, enterprises will choose to implement certain strategies to obtain social resources, such as actively fulfilling corporate environmental responsibility [16]; Du et al. (2016) found that enterprises with serious pollution will take charitable donations to divert public attention from the negative impression of their environmental violations, and such behavior will replace their underdeveloped environmental responsibility to some extent [17]; Many other scholars found that when an enterprise cannot get enough tax incentives, it will obtain them through the means of fulfilling environmental responsibility, thus drawing the conclusion that the actual tax burden of the enterprise is positively related to the environmental responsibility of the enterprise [18]. The above literature enriches the theoretical research in the field of green corporate governance, and provides a certain reference for the practice and academia.

At present, the theoretical research in the field of green governance mainly focuses on how to meet the needs of their own interests and enhance the internal value of enterprises through the implementation of green governance. Limited literature explore the rules of green governance from the characteristics of corporate executives [19], and the attention to the particularity of governance situation of parent-subsidiary companies is also slightly insufficient. As the main decision-maker and operator of an enterprise, senior executives will greatly affect the future development and trend of the enterprise [20]. Therefore, it is particularly necessary to explore the relationship between senior executives' decision-making motivation and green governance from the perspective of senior executives. Enterprise group is a consortium formed by capital as a link. Over the past twenty years, the trend of collectivization of Chinese enterprises has become increasingly obvious, and has made remarkable achievements in the scale of enterprise groups. Enterprise groups gradually 
become the leading force in the development of national economy. Compared with the single enterprise, the governance mechanism of parent-subsidiary company in the framework of enterprise group is more abundant, the formation process of subsidiary company's green governance decision-making is more complex. Executives' synergy allocation of parent and subsidiary companies is a governance mechanism for parent company to coordinate and centralize subsidiary executives through concurrent executives. It is also an effective way for parent company to control and interfere in subsidiary management decisions. Compared with the senior executives themselves, the executives' synergy allocation of parent and subsidiary companies pay more attention to the special arrangement of senior executives' positions at the level of enterprise groups. For example, a manager is appointed by an enterprise group to serve as an executive in a subsidiary while serving in a parent company [21]. Through the relevant research on the executives' synergy allocation of parent and subsidiary companies under enterprise groups, we can not only explore the individual behavior motivation of senior executives, but more importantly, we can better understand the differences in decision-making intentions of senior executives due to the arrangement of positions within enterprise groups, and provide more empirical evidence for the special governance situation of parent-subsidiary companies under the current enterprise group framework.

Based on the special situation of parent subsidiary corporate governance in the framework of enterprise group, this paper examines the relationship between the executives' synergy allocation and green governance level in parent and subsidiary companies. The possible contributions include: firstly, explore the governance effect of the executives' synergy allocation of parent and subsidiary companies, and examine whether the dual identity executives led by the executives' synergy allocation will attend to one thing and lose sight of another, which will enrich the research on the relationship among executives in the group framework. Secondly, the path to improve the level of green governance is clarified, the impact mechanism of green governance is deeply understood, and the research level and green governance system is also enriched $[1,3]$.

The remainder of this paper is organized as follows. Section 2 explains the theoretical basis and reviews related literature of corporate governance, then develops the research hypothesis. Section 3 demonstrates the research design, introduces the samples and data, the measurement of variables and the research models. Section 4 describes the empirical results and discussion in detail. Section 5 is the summary of conclusions and managerial implications.

\section{Theoretical Analysis and Hypothesis Development}

\section{Exploration of the Influence Mechanism between the Executives' Synergy Allocation and Green Governance Level in Parent And Subsidiary Companies Based on Agency Theory}

In the case of holding relative control of the company, although the subsidiary company within the group framework has the status of legal person independent of the parent company with its own corporate governance system, and has certain independence and flexibility in operation. In essence, a series of subsidiary business activities will inevitably be affected and interfered by the parent company with the status of controlling shareholder, and agency problems appear lead by information asymmetry between the parent and the subsidiary company [22-23]. Due to the different ownership structure, agency problem often presents two different ways of expression. The first kind of agency problem is mainly due to the scattered shareholding ratio of the principal and the lack of adequate supervision over the agent, which makes the agent often conduct opportunistic behavior based on self-interest motivation to damage the interests of the company [24]. The second type of agency problem mainly refers to the fact that the largest shareholder in the company will infringe on the interests of the company's small and medium shareholders through connected transactions, mortgage guarantees, or shareholding, based on its own higher control rights, and the private gains of control rights, to achieve the purpose of self-interest grabbing [25-27]. China's listed companies often have a high degree of equity concentration, compared with other countries, the second type of agency problem is more serious. When there is a serious agency problem, it means that due to the lengthy agency chain between parent and subsidiary companies, which has a high degree of information asymmetry, the parent company's supervision cost of the subsidiary's operating activities will increase, which will lead to the parent company's risk sensitivity to the subsidiary company increasing. Therefore, the parent company will have certain shortsighted behavior in this situation out of consideration of its own existing interests [28-29]. For example, it encroaches on the interests of minority shareholders of subsidiaries through tunneling behaviors such as corporate assets encroachment and related party transactions [30-31]. Considering the resource consumption of green governance decision itself and the lack of obvious short-term benefits, the parent company pays more attention to how to grab its own interests from the subsidiaries [32], instead of focusing on promoting the environmental responsibility behaviors such as green governance of the subsidiaries, and even has a negative attitude towards the green governance behaviors of the subsidiaries. 
From the perspective of alleviating information asymmetry, the executives' synergy allocation of parent-subsidiary companies makes some executives of subsidiary companies have dual identities. As a member of strategic decision-making of subsidiary companies, executives can not only obtain explicit information about subsidiary companies' generalization, but also obtain subsidiary companies' green governance heterogeneous "recessive information" by participating in the formulation of a series of subsidiary companies' green governance strategic plans [33]. And through the corresponding way to make the parent company aware of the subsidiary company's decision-making trend on green governance, so that the parent company will guide and supervise the subsidiary company's green governance activities with more target; which will be beneficial to improve the subsidiary company's green governance level. At the same time, the executives' synergy allocation alleviates the agency problem between parent and subsidiary companies. At this time, the shortsighted opportunism of parent company with shareholder status will be weakened. Instead, it will focus on the long-term interests and the sustainable development of subsidiary companies, strengthen communication and cooperation with stakeholders, and also have the motivation to urge subsidiary companies to actively assume environmental responsibility. Based on this, we suggest the following hypothesis:

Hypothesis 1a. Executives' synergy allocation of parent and subsidiary companies has a positive impact on the green governance of subsidiary companies.

Exploration of the Influence Mechanism of Parent-Subsidiary Executives' Synergy Allocation on Green Governance Level of Subsidiaries Based on the Role Theory

However, the role theory challenges the positive correlation between the green governance level and executives' synergy allocation of parent and subsidiary companies. Firstly, according to the role theory, there are role conflicts and role ambiguities in complex organizations, which lead to the loss of individual and organization functions [34]. Role conflict refers to the fact that if the expectations and requirements of a role are inconsistent or conflict, the undertaker of the role can hardly satisfy the expectations of one of the roles while satisfying the expectations of the other [35]. If the executives work in both parent company and subsidiary company, then the concurrent executives of subsidiary company will face role conflict and need to perform their responsibilities from both sides. Moreover, both parent company and subsidiary company have expectations for concurrent executives. This dual identity will make concurrent executives feel anxious and at a loss, which makes it difficult to make reasonable corporate governance decisions effectively during the operation of companies [36]. Secondly, role ambiguity occurs when concurrent executives lack relevant information about their expectations and regulations for a given role and are uncertain about their roles [37]. This leads to self-interest motive. Moreover, green governance as a "public affairs activity" [7], the adoption of green governance such as social responsibility behaviors will not increase corporate performance in the short term, or even result in additional cost expenditure, which is contrary to the personal performance pursuit of concurrent executives [38-39]. In this case, the implementation of green governance may not be relevant to the economic performance of concurrent executives, and concurrent executives may even have a negative attitude towards it, which is not conducive to the improvement of the subsidiaries' green governance level. Therefore, based on this, we propose the following hypothesis as competitive hypothesis of Hla:

Hypothesis 1b. Executives' synergy allocation of parent and subsidiary companies negatively affects the green governance of subsidiary companies.

Contingency Thoughts on the Relationship between Executives' Synergy Allocation of Parent-Subsidiary Companies and Green Governance of Subsidiary Companies

\section{The Contingency Effect of Checks and Balances of Other Major Shareholders of Subsidiaries}

The concentration of equity checks and balances refer to a power checks and balances mechanism in which more than two major shareholders share the control rights of a company in the equity structure of a listed company, which embodies the checks and balances ability of other major shareholders to controlling shareholders [40]. Equity checks and balances have equity effects. Interest demands will increase the enthusiasm of other major shareholders to participate in corporate governance and supervise the behavior of controlling shareholders, increase the cost of controlling shareholders transferring resources of listed companies, and alleviate the second kind of agency problems [4142]. Executives' synergy allocation of parent-subsidiary executives is the design and arrangement of parent company's governance structure for subsidiaries on the basis of controlling position. In view of the possibility of parent company's tunneling behavior, other major shareholders have a stronger sense of supervision and distrust of these dual-status executives, and will actively seek voice rights and access rights to information, so as to restrict controlling and interference behavior of parent companies during subsidiaries decisionmaking process [43-44]. Whether concurrent executives implement green governance activities or not, other major shareholders of listed companies will believe that concurrent executives' actions may be beneficial to the parent company to seize private interests and damage the value of listed companies, thus restricting and supervising concurrent executives' decisions of major shareholders will weaken the governance effect of 
executives' synergy allocation of parent and subsidiary companies. Moreover, the higher the equity checks and balances degree, the stronger the motivation and ability of restraint and supervision, the weaker the governance effect executives' synergy allocation. Based on the above analysis, the following hypothesis is put forward:

Hypothesis 2. The lower the equity checks and balances, the stronger the positive impact of executives' synergy allocation of parent and subsidiary companies on the green governance level of subsidiaries.

\section{The Contingency Effect of Property Right Nature of Enterprise Group}

The different property rights nature of enterprise groups has a significant impact on the governance effect of parent-subsidiary executives' synergy allocation. This is because: firstly, compared with private enterprise groups, state-owned enterprise groups have the color of planned system and administrative management. The driving factors of parent-subsidiary executives' synergy allocation may not come from the active governance needs of parent companies, and the characteristics of political appointment are difficult to play an incentive role on concurrent executives under negative institutional pressure [45], the development of individual competence and the willingness to govern are inhibited [46]. It is difficult to give full play to the enthusiasm, initiative, and creativity of concurrent executives, nor to make scientific decisions on the actual situation of subsidiaries. Secondly, in general, the characteristics of the state-owned enterprise group, such as multilevel management, large-scale management, information transmission "layers down, layers report", make the information transmission chain between parent and subsidiary companies too long [47]. It may lead to the distortion of information transmission and the time lag of feedback process. The decision-making and governance efficiency of concurrent executives will undoubtedly be affected. Therefore, compared with private enterprise groups, the governance effect of executives' synergy allocation in state-owned enterprise groups cannot be fully exerted. Based on the above analysis, the following hypothesis is proposed:

Hypothesis 3. Compared with state-owned enterprise groups, the executives' synergy allocation of parent-subsidiary companies in private enterprise groups has a stronger impact on the green governance of subsidiaries.

The overall study model is shown in Fig. 1.

\section{Methodology and Variable Definitions}

\section{Methodology}

This paper uses empirical analysis method to test the proposed hypothesis, taking listed manufacturing companies in Shanghai and Shenzhen Stock Exchanges as initial samples, and further screens them through the following steps: firstly, enterprises belong to enterprise groups and the controlling shareholders are corporate enterprises; secondly, there are no major reorganization phenomena such as the change of controlling shareholders during the sample observation from 2014 to 2017; thirdly, ST and data are excluded. The observation companies that suffered "Special Treatment" (ST) and *ST (stocks that have been warned of delisting risks) during the sample observation period from 2014 to 2017 and the companies whose data were seriously missing were all deleted in this study. "ST" stands that in China, listed companies with abnormal financial problems would be warned of delisting risks. "Seriously missing" refers to situation when sample companies' data used to measure the important variables cannot be found in any way. Finally, 3100 groups of samples were obtained, and the number of samples in four-year observation

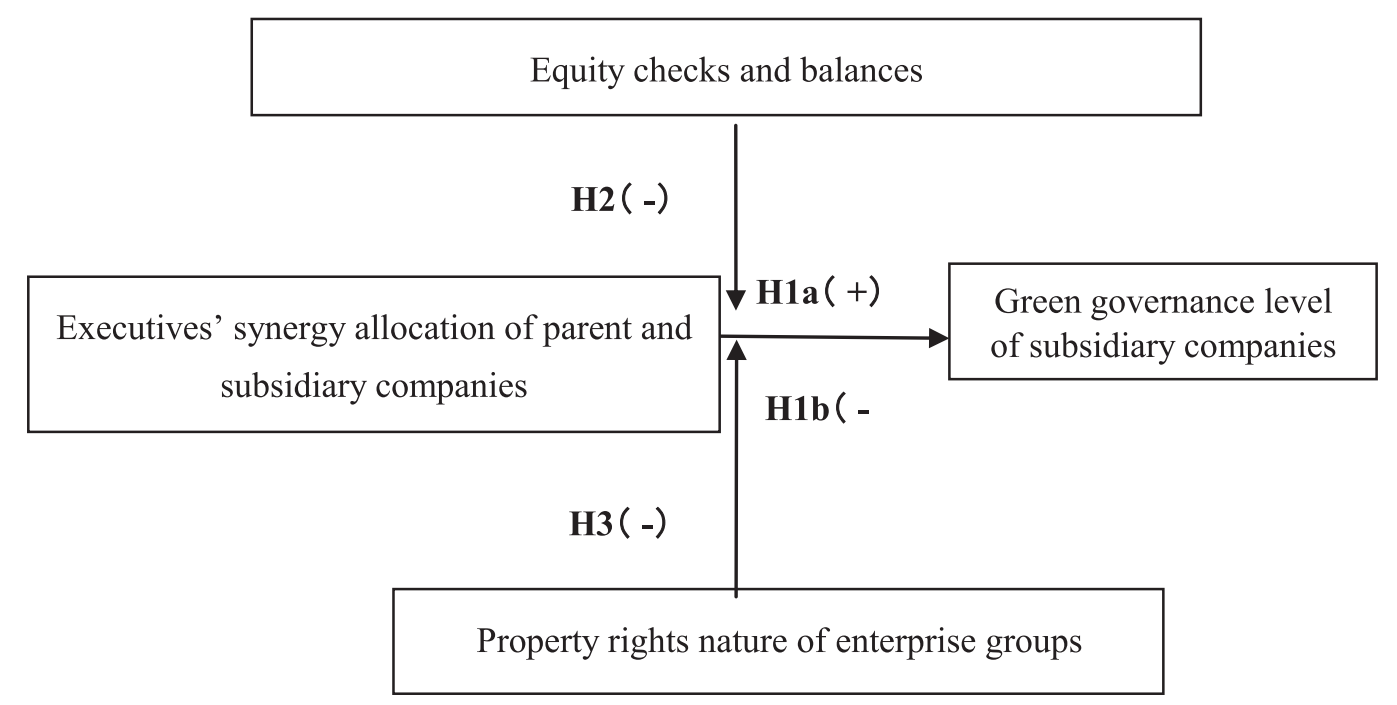

Fig. 1. Hypothesized model. 
period was $772,776,776$ and 776 , respectively. The other relevant data used in this empirical analysis are mainly from CSMAR database. (CSMAR database is an economic and financial database developed from the needs of academic research).

\section{Variable Definitions}

Green governance level. As a part of information disclosure, environmental information disclosure not only reflects the level of corporate governance, but also affects the confidence and attitude of external investors, which is of great help to the long-term development and good reputation of the company. Meng et al. (2014) believed that environmental information disclosure can express the status quo of green governance of enterprises [48]. In order to distinguish enterprises with superior environmental performance from other enterprises with bad environmental performance, enterprises tend to disclose more environmental information to show their legitimacy. To sum up, environmental information disclosure, as an illustration of enterprises' environmental governance status to the outside world, can largely represent the green governance level of enterprises. Therefore, this paper uses the disclosure of sustainable development information, environmental information, and social responsibility system construction information of listed companies to measure the green governance level of enterprises. The measurement method is evaluated from three aspects: whether to disclose environmental information according to GRI (Guidelines for Sustainable Development Report), whether to disclose environmental and sustainable development information, and whether to disclose the construction and improvement measures of social responsibility system. If meets one condition, it is recorded as 1 , otherwise it is recorded as 0 , and finally forms $0-3$ discrete data.

\section{Independent Variables}

Executives' synergy allocation reflects the governance mechanism adopted by the enterprise group in order to realize the advantages of parentsubsidiary cooperation and achieve unified coordination and centralized allocation of senior executives within the group. Based on the previous research [49] and

Table 1. Definition and measurement of variables.

\begin{tabular}{|c|c|c|}
\hline Variables & Code & Index \\
\hline Green governance level & GG & $\begin{array}{l}\text { Whether to disclose environmental information according to GRI } \\
\text { (Guidelines for Sustainable Development Report), whether to disclose } \\
\text { environmental and sustainable development information, and whether } \\
\text { to disclose the construction and improvement measures of social } \\
\text { responsibility system. If meets one condition, it is recorded as } 1 \text {, } \\
\text { otherwise it is recorded as } 0 \text {, and finally forms } 0-3 \text { discrete data. }\end{array}$ \\
\hline Executives' synergy allocation & ES & $\begin{array}{c}\text { Measured by the ratio of the number of subsidiary executives } \\
\text { concurrently serving as executives in parent company to the total } \\
\text { number of subsidiary executives. }\end{array}$ \\
\hline Equity checks and balances & EB & $\begin{array}{l}\text { Measured by the ratio of the proportion sum of the } 2-10 \text { major } \\
\text { shareholders to the first major shareholders. }\end{array}$ \\
\hline Property rights nature of enterprise group & $\mathrm{PN}$ & $\begin{array}{c}\text { Private enterprise group is marked with } 0 \text {, state-owned enterprise group } \\
\text { is marked with } 1 .\end{array}$ \\
\hline Firm size & Employees & $\begin{array}{l}\text { The natural logarithm of the number of employees at the end of the } \\
\text { year }\end{array}$ \\
\hline Board leadership structure & BLS & $\begin{array}{l}\text { Measured as follows: Part-time situation of chairman and CEO. When } \\
\text { two positions were held by one person, this indicator was marked as } \\
\text { "1", otherwise this indicator was marked as "0". }\end{array}$ \\
\hline Capital structure & $\mathrm{CS}$ & Measured by debt ratio (total debt to total assets). \\
\hline Profitability & ROE & $\begin{array}{l}\text { Measured by rate of return on net assets: ratio of after-tax profit to } \\
\text { owner's equity. }\end{array}$ \\
\hline Operational capability & $\mathrm{OC}$ & $\begin{array}{l}\text { Measured by current asset turnover, the ratio of operating revenues to } \\
\text { liquidity balance at the end of the period. }\end{array}$ \\
\hline Analysts' attention & Analysts & $\begin{array}{l}\text { Measured by the sum of number of surveys conducted by analysts and } \\
\text { the number of reports analyzed. }\end{array}$ \\
\hline Year (2015) & Y1 & Observation year belongs to this year, recorded as 1 , not 0 . \\
\hline Year (2016) & Y2 & Observation year belongs to this year, recorded as 1 , not 0 . \\
\hline Year (2017) & Y3 & Observation year belongs to this year, recorded as 1 , not 0 . \\
\hline
\end{tabular}


the operation environment of China, this paper uses the ratio of the number of subsidiary executives concurrently serving as executives in parent company to the total number of subsidiary executives to measure.

\section{Moderating Variable}

Equity checks and balances. Equity checks and balances reflect the checks and balances of the previous major shareholders of the company. This paper measures with the ratio of the proportion sum of the 2-10 major shareholders to the first major shareholders.

Property rights nature of enterprise Group (PN). Wide disagreements about the nature of rural enterprise in China have encouraged many scholars' research; property rights and the nature of the firm may affect the corporate governance efficiency to some extent [5051]. Combing with previous scholars' research, Property rights nature of enterprise group is a dummy variable. Private enterprise group is marked with 0; state-owned enterprise group is marked with 1 [52-53].

\section{Control Variables}

In addition, combined with the existing research, the following factors reflecting the characteristics of subsidiaries are selected as control variables: firm size, board leadership structure, capital structure, profitability, operational capacity, analyst attention, observation year. Referring to previous studies, we measure firm size from the number of employees [54]. Because of the difference of data magnitude, we take logarithm of the original data of the indicator in empirical analysis. Board leadership structure is measured as follows: Part-time situation of chairman and CEO. When two positions were held by one person, this indicator was marked as "1", otherwise this indicator was marked as " 0 ". Capital structure is another control variable, which mainly referred to the composition and proportion of various long-term capital, which will greatly affect the innovation investment and business decision-making of enterprises [55]. According to the previous studies, capital structure was measured by debt ratio (total debt to total assets). Profitability is measured by rate of return on net assets: ratio of aftertax profit to owner's equity. Operational capability is measured by current asset turnover. Analysts' attention is the sum of number of surveys conducted by analysts and the number of reports analyzed. Observation year (the annual) measurements are three control variables. Definition and measurement of variables are shown in Table 1.

\section{Models}

To investigate the impact of executives' synergy allocation on green governance level and the moderating effect of equity checks and balances and property rights nature of enterprise group on this relationship, we proposed the following model:
Model (1) is utilized to investigate the relationship between executives' synergy allocation on green governance level. Model (2) is utilized to investigate the moderating effect of equity checks and balances on the above relationship. Models (3) -(4) are utilized to investigate the moderating effect of property rights nature of enterprise group on the relationship between executives' synergy allocation on green governance level.

$$
G G=c+\sum_{j=1}^{9} b_{j} \text { Control }+\alpha_{1} E S+\varepsilon
$$

$G G=c+\sum_{j=1}^{9} b_{j}$ Control $+\alpha_{1} E S+\alpha_{2} E B+\alpha_{3} E S \times E B+\varepsilon$

$$
G G=c+\sum_{j=1}^{9} b_{j} \text { Control }+\alpha_{1} E S+\varepsilon(P N=0)
$$

$$
G G=c+\sum_{j=1}^{9} b_{j} \text { Control }+\alpha_{1} E S+\varepsilon(P N=1)
$$

Control is the group of control variables, $\mathrm{c}$ is the intercept term, $\varepsilon$ is the random disturbance term, $\mathrm{j}$ is the number of each control variable, and $b_{j}$ is the regression coefficient of each control variable. Model 1 is the regression model of executives' synergy allocation and green governance level, which can test hypotheses H1a and H1b. Based on model 1, model 2 adds a moderator equity checks and balances, product item of executives' synergy allocation and equity checks and balances to verify the moderating effect of equity checks and balances on the relationship between executives' synergy allocation and green governance level, that is, to test the rationality of hypothesis H2. Model 3 and Model 4 adds a moderating variable on the basis of model 1 to test the contingency effect of property rights nature of enterprise group on the relationship between executives' synergy allocation and green governance level, that is, to verify whether hypothesis H3 is valid.

\section{Data Analysis and Results Discussion}

\section{Descriptive Statistics}

Table 2 reports the mean, median, standard deviation, minimum and maximum value of the main variables. From Table 2, the average value of green governance of subsidiaries fluctuates between 0.4 and 0.5 , and the four-year average value of green governance is 0.402 . It can be seen that the overall level of green governance of sample companies is relatively low, and the listed companies have a long way to go in improving the level of green governance. The average value of executives' synergy allocation of parent and subsidiary 
Table 2. Descriptive statistics of variables (Means, standard deviations and correlation coefficients of major variables).

\begin{tabular}{|c|c|c|c|c|c|c|}
\hline & Variable & Number of observations & Mean & Standard Deviation & Minimum & Maximum \\
\hline \multirow{4}{*}{2014} & GG & 772 & 0.430 & 0.677 & 0.000 & 3.000 \\
\hline & ES & 772 & 0.174 & 0.111 & 0.000 & 0.583 \\
\hline & $\mathrm{EB}$ & 772 & 0.646 & 0.611 & 0.008 & 6.775 \\
\hline & $\mathrm{PN}$ & 772 & 0.503 & 0.500 & 0.000 & 1.000 \\
\hline \multirow{4}{*}{2015} & GG & 776 & 0.437 & 0.673 & 0.000 & 3.000 \\
\hline & ES & 776 & 0.176 & 0.117 & 0.000 & 0.583 \\
\hline & EB & 776 & 0.687 & 0.614 & 0.011 & 6.340 \\
\hline & $\mathrm{PN}$ & 776 & 0.504 & 0.500 & 0.000 & 1.000 \\
\hline \multirow{4}{*}{2016} & GG & 776 & 0.503 & 0.765 & 0.000 & 3.000 \\
\hline & ES & 776 & 0.174 & 0.122 & 0.000 & 0.583 \\
\hline & $\mathrm{EB}$ & 776 & 0.760 & 0.620 & 0.016 & 4.480 \\
\hline & $\mathrm{PN}$ & 776 & 0.504 & 0.500 & 0.000 & 1.000 \\
\hline \multirow{4}{*}{2017} & GG & 776 & 0.238 & 0.567 & 0.000 & 3.000 \\
\hline & ES & 776 & 0.173 & 0.120 & 0.000 & 0.583 \\
\hline & EB & 776 & 0.778 & 0.621 & 0.019 & 4.474 \\
\hline & $\mathrm{PN}$ & 776 & 0.504 & 0.500 & 0.000 & 1.000 \\
\hline
\end{tabular}

companies is about 0.17 during the four-year period, but the trend and extreme value of standard deviation during the observation period can be seen that there are some differences in the degree of executives' synergy allocation in parent and subsidiary companies between enterprise groups, and the degree of differentiation is gradually expanding; the average value of equity checks and balances shows a gradual growth trend during the observation period, reflecting that the equity checks and balances ability of large shareholders of sample companies to controlling shareholders is constantly increasing, and the standard deviation increases year by year, which also shows that the degree of differentiation of equity checks and balances among sample companies is increasing; The average quality is about 0.5 , which shows that the number of sample companies belonging to state-owned enterprise groups and private enterprise groups is similar.

\section{Multiple Regression Results}

According to the model designed above, multiple regression analysis is carried out using STATA15.1. The specific results are shown in Table 3. The results of M1 regression analysis show that after controlling the various factors that may affect the level of green governance, the regression coefficient of parentsubsidiary executives' synergy allocation is positive $(\beta=0.450)$, which is significant at the level of $10 \%$. This shows that executives' synergy allocation has a positive effect on the level of green governance of subsidiaries.
Thus, H1a is verified, the competitive hypothesis H1b has not passed the test. The results of M2 analysis show that the regression coefficient of the interaction between equity checks and balances and executives' synergy allocation is negative $(\beta=-0.933)$ and is significant at the level of $5 \%$. This shows that equity checks and balances have a significant negative moderating effect on the relationship between executives' synergy allocation and subsidiary green governance level. That is, the lower the equity checks and balances, the effect of executives' synergy allocation on subsidiary green governance level is stronger, thus the hypothesis H2 is verified. The results of M3 and M4 analysis show that the regression coefficient of executives' synergy allocation is positive $(\beta=0.817)$ and significant at the level of $5 \%$. In state-owned enterprise groups, although the regression coefficient of executives' synergy allocation and green governance level is positive $(\beta=0.290)$, it has not passed the significance test, indicating compared with state-owned enterprise groups. In private enterprises, the effect of executives' synergy allocation on subsidiary green governance is stronger, thus, $\mathrm{H} 3$ is verified.

\section{Robustness}

\section{Negative Binomial Regression}

In order to verify the robustness of the conclusions of the article, the selected data are tested for robustness using the negative binomial regression method. 
Table 3. Regression results analysis.

\begin{tabular}{|c|c|c|c|c|}
\hline \multirow[t]{2}{*}{ Variables } & \multicolumn{4}{|c|}{ GG } \\
\hline & M1 & M2 & $\mathrm{M} 3(\mathrm{PN}=0)$ & $\mathrm{M} 4(\mathrm{PN}=1)$ \\
\hline Constant & $\begin{array}{c}-4.786 * * * \\
(-20.89)\end{array}$ & $\begin{array}{c}-4.816 * * * \\
(-20.08)\end{array}$ & $\begin{array}{c}-5.88 * * * \\
(-13.21)\end{array}$ & $\begin{array}{c}-3.506 * * * \\
(-12.37)\end{array}$ \\
\hline \multicolumn{5}{|c|}{ Control variables } \\
\hline Employees & $\begin{array}{c}0.462 * * * \\
(15.64)\end{array}$ & $\begin{array}{c}0.467 * * * \\
(15.75)\end{array}$ & $\begin{array}{c}0.555^{* * *} \\
(9.42)\end{array}$ & $\begin{array}{c}0.343^{* * * *} \\
(9.61)\end{array}$ \\
\hline LS & $\begin{array}{l}-0.117 \\
(-1.51)\end{array}$ & $\begin{array}{l}-0.104 \\
(-1.34)\end{array}$ & $\begin{array}{l}0.082 \\
(0.73)\end{array}$ & $\begin{array}{l}-0.025 \\
(-0.22)\end{array}$ \\
\hline $\mathrm{CS}$ & $\begin{array}{l}-0.192 \\
(-1.14)\end{array}$ & $\begin{array}{l}-0.224 \\
(-1.33)\end{array}$ & $\begin{array}{l}-0.250 \\
(-0.80)\end{array}$ & $\begin{array}{c}-0.336^{*} \\
(-1.68)\end{array}$ \\
\hline ROE & $\begin{array}{l}-0.031 \\
(-0.47)\end{array}$ & $\begin{array}{l}-0.030 \\
(-0.45)\end{array}$ & $\begin{array}{l}0.206 \\
(1.14)\end{array}$ & $\begin{array}{l}-0.036 \\
(-0.57)\end{array}$ \\
\hline $\mathrm{OC}$ & $\begin{array}{l}0.055 \\
(0.79)\end{array}$ & $\begin{array}{l}0.038 \\
(0.53)\end{array}$ & $\begin{array}{l}0.040 \\
(0.30)\end{array}$ & $\begin{array}{l}0.021 \\
(0.26)\end{array}$ \\
\hline Analysts & $\begin{array}{l}0.001^{*} \\
(1.65)\end{array}$ & $\begin{array}{l}0.001 \\
(1.61)\end{array}$ & $\begin{array}{l}-0.000 \\
(-0.11)\end{array}$ & $\begin{array}{c}0.003 * * * \\
(3.27)\end{array}$ \\
\hline Year (2015) & $\begin{array}{l}0.002 \\
(0.03)\end{array}$ & $\begin{array}{l}0.009 \\
(0.11)\end{array}$ & $\begin{array}{l}-0.017 \\
(-0.12)\end{array}$ & $\begin{array}{l}0.024 \\
(0.26)\end{array}$ \\
\hline Year (2016) & $\begin{array}{l}0.119 \\
(1.58)\end{array}$ & $\begin{array}{l}0.130^{*} \\
(1.72)\end{array}$ & $\begin{array}{l}0.090 \\
(0.66)\end{array}$ & $\begin{array}{l}0.149 \\
(1.64)\end{array}$ \\
\hline Year (2017) & $\begin{array}{c}-0.664 * * * \\
(-7.20)\end{array}$ & $\begin{array}{c}-0.650 * * * \\
(-6.99)\end{array}$ & $\begin{array}{c}-0.761^{* * *} \\
(-4.53)\end{array}$ & $\begin{array}{c}-0.630^{* * *} \\
(-5.69)\end{array}$ \\
\hline \multicolumn{5}{|c|}{ Independent variable } \\
\hline ES & $\begin{array}{c}0.450^{*} \\
(1.87) \\
\end{array}$ & $\begin{array}{c}0.900 * * \\
(2.43)\end{array}$ & $\begin{array}{c}0.817 * * \\
(1.98) \\
\end{array}$ & $\begin{array}{l}0.290 \\
(0.97)\end{array}$ \\
\hline \multicolumn{5}{|c|}{ Moderator } \\
\hline EB & & $\begin{array}{l}0.033 \\
(0.37)\end{array}$ & & \\
\hline \multicolumn{5}{|c|}{ Product term } \\
\hline ES*EB & & $\begin{array}{c}-0.933 * * \\
(-1.98)\end{array}$ & & \\
\hline $\mathrm{R}^{2}$ & 0.096 & 0.098 & 0.089 & 0.077 \\
\hline chi2 & 503.11 & 511.84 & 175.73 & 235.85 \\
\hline $\mathrm{N}$ & 3100 & 3100 & 1539 & 1561 \\
\hline
\end{tabular}

Note: Because the dependent variables are discrete data variables, Poisson regression analysis method is adopted. ***,**,* Represents $\mathrm{p}<0.01, \mathrm{p}<0.05, \mathrm{p}<0.1$ respectively.

Table 4. Hypotheses and whether hypotheses are verified.

\begin{tabular}{|c|c|c|}
\hline Hypothesis 1a & $\begin{array}{r}\text { Hypotheses } \\
\text { positive impact on the green governance of subsidiary companies. }\end{array}$ & Whether Hypotheses are Verified \\
\hline Hypothesis 1b & $\begin{array}{r}\text { Executives' synergy allocation of parent and subsidiary companies negatively } \\
\text { affects the green governance of subsidiary companies. }\end{array}$ & NO \\
\hline Hypothesis 2 & $\begin{array}{r}\text { The lower the equity checks and balances, the stronger the positive impact } \\
\text { of executives' synergy allocation of parent and subsidiary companies on the } \\
\text { green governance level of subsidiaries. }\end{array}$ & YES \\
\hline Hypothesis 3 & $\begin{array}{r}\text { Compared with state-owned enterprise groups, the executives' synergy } \\
\text { allocation of parent-subsidiary companies in private enterprise groups has a } \\
\text { stronger impact on the green governance of subsidiaries. }\end{array}$ \\
\hline
\end{tabular}


Table 5. Negative binomial regression analysis results.

\begin{tabular}{|c|c|c|c|c|}
\hline \multirow[t]{2}{*}{ Variables } & \multicolumn{4}{|c|}{ GG } \\
\hline & M1 & M2 & $\mathrm{M} 3(\mathrm{PN}=0)$ & $\mathrm{M} 4(\mathrm{PN}=1)$ \\
\hline Constant & $\begin{array}{l}-4.786^{* * *} \\
(-20.90)\end{array}$ & $\begin{array}{l}-4.817^{\text {**** }} \\
(-20.08)\end{array}$ & $\begin{array}{l}-5.898^{* * *} \\
(-12.03)\end{array}$ & $\begin{array}{l}-3.506^{* * *} \\
(-12.37)\end{array}$ \\
\hline \multicolumn{5}{|c|}{ Control variables } \\
\hline Employees & $\begin{array}{c}0.462^{* * *} \\
(15.64)\end{array}$ & $\begin{array}{l}0.467^{* * * *} \\
(15.75)\end{array}$ & $\begin{array}{c}0.552^{* * *} \\
(8.51)\end{array}$ & $\begin{array}{c}0.343^{* * *} \\
(9.61)\end{array}$ \\
\hline LS & $\begin{array}{l}-0.117 \\
(-1.51)\end{array}$ & $\begin{array}{l}-0.104 \\
(-1.34)\end{array}$ & $\begin{array}{l}0.102 \\
(0.82)\end{array}$ & $\begin{array}{l}-0.025 \\
(-0.22)\end{array}$ \\
\hline $\mathrm{CS}$ & $\begin{array}{l}-0.192 \\
(-1.14)\end{array}$ & $\begin{array}{l}-0.224 \\
(-1.33)\end{array}$ & $\begin{array}{l}-0.193 \\
(-0.58)\end{array}$ & $\begin{array}{l}-0.336^{*} \\
(-1.68)\end{array}$ \\
\hline ROE & $\begin{array}{l}-0.031 \\
(-0.47)\end{array}$ & $\begin{array}{l}-0.030 \\
(-0.45)\end{array}$ & $\begin{array}{l}0.209 \\
(0.98)\end{array}$ & $\begin{array}{l}-0.036 \\
(-0.57)\end{array}$ \\
\hline $\mathrm{OC}$ & $\begin{array}{l}0.055 \\
(0.79)\end{array}$ & $\begin{array}{l}0.038 \\
(0.54)\end{array}$ & $\begin{array}{l}0.036 \\
(0.24)\end{array}$ & $\begin{array}{l}0.021 \\
(0.26)\end{array}$ \\
\hline Analysts & $\begin{array}{l}0.001^{*} \\
(1.65)\end{array}$ & $\begin{array}{l}0.001 \\
(1.61)\end{array}$ & $\begin{array}{l}0.000 \\
(0.19)\end{array}$ & $\begin{array}{c}0.003^{* * *} \\
(3.27)\end{array}$ \\
\hline Year (2015) & $\begin{array}{l}0.002 \\
(0.03)\end{array}$ & $\begin{array}{l}0.009 \\
(0.11)\end{array}$ & $\begin{array}{l}-0.025 \\
(-0.16)\end{array}$ & $\begin{array}{l}0.024 \\
(0.26)\end{array}$ \\
\hline Year (2016) & $\begin{array}{l}0.119 \\
(1.58)\end{array}$ & $\begin{array}{l}0.130^{*} \\
(1.72)\end{array}$ & $\begin{array}{l}0.085 \\
(0.57)\end{array}$ & $\begin{array}{l}0.149 \\
(1.64)\end{array}$ \\
\hline Year (2017) & $\begin{array}{c}-0.664^{* * *} \\
(-7.20)\end{array}$ & $\begin{array}{c}-0.646^{* * *} \\
(-6.99)\end{array}$ & $\begin{array}{c}-0.768^{* * *} \\
(-4.27)\end{array}$ & $\begin{array}{c}-0.629^{* * *} \\
(-5.69)\end{array}$ \\
\hline \multicolumn{5}{|c|}{ Independent variable } \\
\hline ES & $\begin{array}{l}0.451^{*} \\
(1.87)\end{array}$ & $\begin{array}{c}0.903^{* *} \\
(2.44)\end{array}$ & $\begin{array}{l}0.833^{*} \\
(1.84)\end{array}$ & $\begin{array}{l}0.291 \\
(0.97)\end{array}$ \\
\hline \multicolumn{5}{|c|}{ Moderator } \\
\hline EB & & $\begin{array}{l}0.034 \\
(0.38)\end{array}$ & & \\
\hline \multicolumn{5}{|c|}{ Product term } \\
\hline ES*EB & & $\begin{array}{c}-0.938^{* *} \\
(-1.99)\end{array}$ & & \\
\hline $\mathrm{R}^{2}$ & 0.089 & 0.091 & 0.072 & 0.076 \\
\hline chi2 & 463.55 & 472.31 & 139.52 & 235.48 \\
\hline $\mathrm{N}$ & 3100 & 3100 & 1539 & 1561 \\
\hline
\end{tabular}

Note: Because the dependent variables are discrete data variables, negative binomial regression analysis method is adopted. $* * *, * *$,

$*$ Represents $\mathrm{p}<0.01, \mathrm{p}<0.05, \mathrm{p}<0.1$ respectively.

As can be seen from Table 5, in Model 1, the regression coefficient of executives' synergy allocation on green governance is positive $(\beta=0.451)$ and significant on the basis of $10 \%$. In Model 2, the product term coefficient of equity checks and balances and executives' synergy allocation is negative $(\beta=-0.938)$ and significant on the basis of 5\%. After distinguishing the nature of property rights (Model 3 and Model 4), the regression coefficient of executives' synergy allocation on green governance in the sample of private enterprises is positive $(\beta=0.833)$, and significant on the basis of $10 \%$, while the coefficient of state-owned enterprises is positive $(\beta=0.291)$, but not significant.
The above tests are consistent with the assumptions in this paper, which proves the robustness of the research conclusions.

\section{Add Control Variables}

In addition, considering that the equity pledge behavior (EP) of the controlling shareholder will affect the decision-making of the subsidiary in coordination with the senior management, and when there are multiple large shareholders (Multi) in the enterprise, due to the high shareholding ratio of the large shareholders, the decision-making motivation of the parent company 
Table 6. Add Control Variables.

\begin{tabular}{|c|c|c|c|c|}
\hline \multirow[t]{2}{*}{ Variables } & \multicolumn{4}{|c|}{ GG } \\
\hline & M1 & M2 & $\mathrm{M} 3(\mathrm{PN}=0)$ & M4 $(\mathrm{PN}=1)$ \\
\hline Constant & $\begin{array}{l}-4.612^{* * *} \\
(-17.43)\end{array}$ & $\begin{array}{l}-4.687^{* * *} \\
(-17.05)\end{array}$ & $\begin{array}{l}-6.203^{* * *} \\
(-12.31)\end{array}$ & $\begin{array}{l}-3.554^{* * *} \\
(-11.01)\end{array}$ \\
\hline \multicolumn{5}{|c|}{ Control variables } \\
\hline Employees & $\begin{array}{l}0.453^{* * *} \\
(13.24)\end{array}$ & $\begin{array}{l}0.459^{* * * *} \\
(13.33)\end{array}$ & $\begin{array}{c}0.572^{\text {*** }} \\
(8.80)\end{array}$ & $\begin{array}{c}0.366^{* * *} \\
(8.85)\end{array}$ \\
\hline LS & $\begin{array}{l}-0.122 \\
(-1.41)\end{array}$ & $\begin{array}{l}-0.114 \\
(-1.31)\end{array}$ & $\begin{array}{l}0.065 \\
(0.51)\end{array}$ & $\begin{array}{l}-0.077 \\
(-0.63)\end{array}$ \\
\hline $\mathrm{CS}$ & $\begin{array}{c}-0.374^{* *} \\
(-2.04)\end{array}$ & $\begin{array}{c}-0.401^{* *} \\
(-2.18)\end{array}$ & $\begin{array}{l}-0.184 \\
(-0.53)\end{array}$ & $\begin{array}{c}-0.613^{* * * *} \\
(-2.79)\end{array}$ \\
\hline ROE & $\begin{array}{l}-0.024 \\
(-0.32)\end{array}$ & $\begin{array}{l}-0.021 \\
(-0.29)\end{array}$ & $\begin{array}{l}0.205 \\
(1.12)\end{array}$ & $\begin{array}{l}-0.039 \\
(-0.59)\end{array}$ \\
\hline $\mathrm{OC}$ & $\begin{array}{l}0.055 \\
(0.72)\end{array}$ & $\begin{array}{l}0.045 \\
(0.57)\end{array}$ & $\begin{array}{l}0.022 \\
(0.15)\end{array}$ & $\begin{array}{l}0.042 \\
(0.46)\end{array}$ \\
\hline Analysts & $\begin{array}{c}0.003^{* * * *} \\
(2.68)\end{array}$ & $\begin{array}{c}0.002^{* * * *} \\
(2.62)\end{array}$ & $\begin{array}{l}0.000 \\
(0.26)\end{array}$ & $\begin{array}{c}0.004^{* * *} \\
(3.38)\end{array}$ \\
\hline EP & $\begin{array}{c}-0.432^{* * *} \\
(-5.49)\end{array}$ & $\begin{array}{c}-0.421^{* * *} \\
(-5.32)\end{array}$ & $\begin{array}{l}-0.186 \\
(-1.59)\end{array}$ & $\begin{array}{l}-0.204 \\
(-1.48)\end{array}$ \\
\hline Multi & $\begin{array}{l}-0.119^{*} \\
(-1.81)\end{array}$ & $\begin{array}{l}-0.117^{*} \\
(-1.79)\end{array}$ & $\begin{array}{l}0.158 \\
(1.35)\end{array}$ & $\begin{array}{c}-0.226^{* * * *} \\
(-2.84)\end{array}$ \\
\hline Year(2015) & $\begin{array}{l}0.039 \\
(0.46) \\
\end{array}$ & $\begin{array}{l}0.046 \\
(0.54) \\
\end{array}$ & $\begin{array}{l}-0.014 \\
(-0.09) \\
\end{array}$ & $\begin{array}{l}0.040 \\
(0.39) \\
\end{array}$ \\
\hline Year(2016) & $\begin{array}{c}0.212^{* *} \\
(2.56)\end{array}$ & $\begin{array}{c}0.219^{* * * *} \\
(2.64)\end{array}$ & $\begin{array}{l}0.144 \\
(0.95)\end{array}$ & $\begin{array}{l}0.200^{* *} \\
(2.01)\end{array}$ \\
\hline Year(2017) & $\begin{array}{c}-0.594^{* * *} \\
(-5.83) \\
\end{array}$ & $\begin{array}{c}-0.582^{* * *} \\
(-5.70) \\
\end{array}$ & $\begin{array}{c}-0.769^{* * *} \\
(-3.99) \\
\end{array}$ & $\begin{array}{c}-0.585^{* * *} \\
(-4.86) \\
\end{array}$ \\
\hline \multicolumn{5}{|c|}{ Independent variable } \\
\hline ES & $\begin{array}{l}0.484^{*} \\
(1.84) \\
\end{array}$ & $\begin{array}{l}1.004^{* * *} \\
(2.53)\end{array}$ & $\begin{array}{c}1.311^{* * *} \\
(2.93) \\
\end{array}$ & $\begin{array}{l}0.185 \\
(0.56) \\
\end{array}$ \\
\hline \multicolumn{5}{|c|}{ Moderator } \\
\hline EB & & $\begin{array}{l}0.073 \\
(0.79) \\
\end{array}$ & & \\
\hline \multicolumn{5}{|c|}{ Product term } \\
\hline $\mathrm{ES} * \mathrm{~EB}$ & & $\begin{array}{c}-1.053 * * \\
(-2.08) \\
\end{array}$ & & \\
\hline $\mathrm{R}^{2}$ & 0.108 & 0.110 & 0.099 & 0.084 \\
\hline chi2 & 486.34 & 493.34 & 165.47 & 225.26 \\
\hline $\mathrm{N}$ & 3100 & 3100 & 1539 & 1561 \\
\hline
\end{tabular}

Note: Because the dependent variables are discrete data variables, poisson regression analysis method is adopted. ***, **, * Represents $\mathrm{p}<0.01, \mathrm{p}<0.05, \mathrm{p}<0.1$ respectively.

Further analysis: Path analysis of the role of the executives' synergy allocation of parent-subsidiary companies on subsidiary companies' green governance

to the subsidiary will be affected by means of voting by hand and fighting for control, thus affecting the degree of green governance of the subsidiary. Therefore, the study controls the controlling shareholder's equity pledge variable (EP) and multiple large shareholders variable (Multi), both of which have been shown as $0-1$ dummy variables. The test results are shown in Table 6, in model 1, the regression coefficient of executives' synergy allocation on green governance is positive $(\beta=0.484)$ and significant on the basis of $10 \%$. In Model 2, the product term coefficient of equity checks and balances and executives' synergy allocation is negative $(\beta=-1.053)$ and significant on the basis of $5 \%$. After distinguishing the nature of property rights 
Table 7. Further Regression results.

\begin{tabular}{|c|c|c|c|c|}
\hline Variables & GG & $\mathrm{AC}$ & \multicolumn{2}{|c|}{ GG } \\
\hline & M5 & M6 & M7 & M8 \\
\hline Constant & $\begin{array}{c}-4.786 * * * \\
(-20.89)\end{array}$ & $\begin{array}{c}0.557 * * * \\
(23.62)\end{array}$ & $\begin{array}{c}-4.455^{* * *} \\
(-18.24)\end{array}$ & $\begin{array}{c}-4.523 * * * \\
(-18.26)\end{array}$ \\
\hline \multicolumn{5}{|c|}{ Control variables } \\
\hline Employers & $\begin{array}{c}0.462 * * * \\
(15.64)\end{array}$ & $\begin{array}{c}-0.033 * * * \\
(-10.22)\end{array}$ & $\begin{array}{c}0.454 * * * \\
(15.31)\end{array}$ & $\begin{array}{c}0.453 * * * \\
(15.25)\end{array}$ \\
\hline LS & $\begin{array}{l}-0.117 \\
(-1.51)\end{array}$ & $\begin{array}{c}-0.019 * * \\
(-2.36)\end{array}$ & $\begin{array}{c}-0.131^{*} \\
(-1.69)\end{array}$ & $\begin{array}{l}-0.120 \\
(-1.54)\end{array}$ \\
\hline $\mathrm{CS}$ & $\begin{array}{l}-0.192 \\
(-1.14)\end{array}$ & $\begin{array}{c}-0.128 * * * \\
(-7.32)\end{array}$ & $\begin{array}{c}-0.296^{*} \\
(-1.71)\end{array}$ & $\begin{array}{c}-0.309^{*} \\
(-1.78)\end{array}$ \\
\hline ROE & $\begin{array}{l}-0.031 \\
(-0.47)\end{array}$ & $\begin{array}{c}-0.016^{* *} \\
(-2.29)\end{array}$ & $\begin{array}{l}-0.037 \\
(-0.57)\end{array}$ & $\begin{array}{l}-0.037 \\
(-0.56)\end{array}$ \\
\hline $\mathrm{OC}$ & $\begin{array}{l}0.055 \\
(0.79)\end{array}$ & $\begin{array}{c}-0.121 * * * \\
(-15.75)\end{array}$ & $\begin{array}{l}-0.015 \\
(-0.21)\end{array}$ & $\begin{array}{l}-0.016 \\
(-0.21)\end{array}$ \\
\hline Analysts & $\begin{array}{l}0.001^{*} \\
(1.65)\end{array}$ & $\begin{array}{c}0.001 * * * \\
(8.09)\end{array}$ & $\begin{array}{c}0.002 * * \\
(2.10)\end{array}$ & $\begin{array}{c}0.002^{* *} \\
(2.16)\end{array}$ \\
\hline Year(2015) & $\begin{array}{l}0.002 \\
(0.03)\end{array}$ & $\begin{array}{l}0.003 \\
(0.33)\end{array}$ & $\begin{array}{l}0.006 \\
(0.08)\end{array}$ & $\begin{array}{l}0.005 \\
(0.07)\end{array}$ \\
\hline Year(2016) & $\begin{array}{l}0.119 \\
(1.58)\end{array}$ & $\begin{array}{l}0.004 \\
(0.47)\end{array}$ & $\begin{array}{l}0.120 \\
(1.59)\end{array}$ & $\begin{array}{l}0.120 \\
(1.59)\end{array}$ \\
\hline Year(2017) & $\begin{array}{c}-0.664 * * * \\
(-7.20)\end{array}$ & $\begin{array}{l}-0.010 \\
(-1.18)\end{array}$ & $\begin{array}{c}-0.668 * * * \\
(-7.24)\end{array}$ & $\begin{array}{c}-0.670 * * * \\
(-7.26)\end{array}$ \\
\hline \multicolumn{5}{|c|}{ Independent variables } \\
\hline ES & $\begin{array}{l}0.450^{*} \\
(1.87)\end{array}$ & $\begin{array}{c}-0.081 * * * \\
(-3.01)\end{array}$ & & $\begin{array}{l}0.428^{*} \\
(1.77)\end{array}$ \\
\hline \multicolumn{5}{|c|}{ Mediating variables } \\
\hline $\mathrm{AC}$ & & & $\begin{array}{c}-0.698 * * * \\
(-2.65)\end{array}$ & $\begin{array}{c}-0.682 * * * \\
(-2.60)\end{array}$ \\
\hline $\mathrm{R}^{2}$ & 0.096 & 0.182 & 0.097 & 0.098 \\
\hline chi2 & 503.11 & 68.78 & 507.99 & 511.09 \\
\hline $\mathrm{N}$ & 3100 & 3100 & 3100 & 3100 \\
\hline
\end{tabular}

Note: M5, M7 and M8 were Poisson regression analysis, ${ }^{* * *},{ }^{* *},{ }^{*}$ represents $\mathrm{p}<0.01, \mathrm{p}<0.05, \mathrm{p}<0.1$ respectively.

(Model 3 and Model 4), the regression coefficient of executives' synergy allocation on green governance in the sample of private enterprises is positive $(\beta=1.311)$, and significant on the basis of $1 \%$, while the coefficient of state-owned enterprises is positive $(\beta=0.185)$, but not significant. The above results prove that, after controlling other relevant variables that may affect the research results, it is assumed that the results are still consistent with the previous ones, thus verifying the robustness of the conclusions in this paper.

In the previous regression analysis, hypothesis H1a proves that executives' synergy allocation has a positive impact on subsidiary's green governance. Further investigation of the role of executives' synergy allocation in subsidiary green governance can further clarify the internal logic of subsidiary green governance, analyze the legitimacy of hypothetical reasoning logic, and provide a reference for future research. In order to further confirm whether executives' synergy allocation will have a positive impact on green governance by alleviating agency problems and improving governance quality, this paper chooses agency cost (AC) subsidiary of as an intermediary variable to test. According to the study of Rashid et al. (2016) [56], this paper takes the management cost rate as the measurement index of agency cost, examines the mediating role of agency cost of subsidiary companies through the following steps: firstly, the main effect test is carried out to examine the impact of executives' synergy allocation on the green governance level of subsidiary companies; secondly, the correlation between independent variables and mediating variables is tested to examine the impact of executives' synergy allocation on agency cost of subsidiary companies; Thirdly, we test the correlation 
between mediating variables and dependent variables to examine the impact of subsidiary agency costs on the level of green governance; fourthly, we add subsidiary agency costs into the main effect test model to observe the changes of the main effect.

According to the analysis above, this paper uses STATA15.1 to make regression, the results of four steps are shown in Table 4. The results of M5 regression show that the regression coefficient of the main effect of executives' synergy allocation on subsidiary's green governance level is positive $(\beta=0.450)$, and significant at the level of $10 \%$. The results of M6 regression show that the regression coefficient of executives' synergy allocation is negative $(\beta=-0.081)$, and significant at the level of $1 \%$. This shows that executives' synergy allocation has a negative impact on agency cost. The impact is that executives' synergy allocation is conducive to alleviating agency problems caused by information asymmetry. The results of M8 regression show that the regression coefficient of executives' synergy allocation is positive $(\beta=0.428)$, but it is lower than the previous results. This shows that agency cost plays a part of mediating role in the relationship between executives' synergy allocation and subsidiary green governance, that is, part of the positive impact of executives' synergy allocation on green governance is achieved by reducing agency costs.

\section{Research Conclusions and Enlightenment}

\section{Research Conclusions}

In view of the important value of green governance to the healthy growth of listed companies and the sustainable development of national economy [57], based on principal-agent theory and role theory, starting from the particularity of the governance situation of parent-subsidiary companies at the enterprise group level, this paper explores the influence mechanism of executives' synergy allocation of parent and subsidiary companies on subsidiaries' green governance, and the contingency influence of equity checks and balances and property rights in their relationship, and further studies verify the intermediary role of agency costs in executives' synergy allocation of parent-subsidiary companies and green governance. The main conclusions and inspirations are as follows:

Firstly, the empirical results show that the executives' synergy allocation of parent-subsidiary has a positive impact on the green governance of subsidiaries, and this impact is partly achieved by alleviating agency problems. Secondly, this paper verifies the moderating effect of other major shareholders' equity checks and balances on the impact of parent-subsidiary executives' synergy allocation on subsidiary companies' green governance. Specifically, compared with the higher equity checks and balances situation, when the other major shareholders' equity checks and balances ability is weak, the positive impact of executives' synergy allocation on subsidiary companies' green governance is stronger. Similar to previous studies by scholars [5859], the validation of this conclusion further illustrates the objective interaction between equity checks and balances and other governance elements in the process of corporate governance. Finally, the differences in property right nature of enterprise groups will moderate the relationship between executives' synergy allocation of parent-subsidiary and subsidiary green governance. The specific manifestation is that compared with stateowned enterprise groups, executives' synergy allocation of parent-subsidiary in private enterprise groups has a stronger positive impact on subsidiary green governance.

\section{Managerial Implications}

Firstly, validation of the first hypothesis shows the positive significance of parent-subsidiary executives' synergy allocation in improving the governance efficiency and management quality of subsidiaries within the framework of the group, that is, dual-identity executives will not "Attend to One Thing and Lose Sight of Another" in the process of governance, affirms the positive value of this special governance mechanism within the framework of the group, and further illustrates that the implementation of parent-subsidiary executives' synergy allocation mechanism should be encouraged in practice. Moreover, in order to give full play to the positive value of executives' synergy allocation mechanism, we can further optimize the executive selection mechanism of subsidiary companies, alleviate the agency problem of parent and subsidiary companies, and improve the green governance level of subsidiary companies by constructing the schemes of parent and subsidiary company executives' synergy allocation job demand evaluation, parent and subsidiary company executives' synergy allocation mechanism degree determination.

Secondly, the second conclusion of this study shows that equity checks and balances do not always improve the scientific nature of corporate governance decisions. Information asymmetry and other factors make other major shareholders of listed companies lack trust in the governance behavior of controlling shareholders, which leads to internal friction, which is not conducive to the formation and implementation of scientific governance decisions. Therefore, in the future practice, we should further improve the supervision mechanism of other shareholders on listed companies and controlling shareholders. While constantly improving the enthusiasm of minority shareholders to participate in corporate governance, we should strive to play an active role of equity checks and balances. For example, we should continue to optimize the information disclosure system of listed companies, alleviate the degree of information asymmetry between controlling shareholders and other shareholders, 
enhance the shareholders' interest and improve trust degree between subsidiaries, which all can reduce the obstacles that subsidiaries may face in making green governance decisions.

The validation of the third conclusion reflects that the property right nature as a situational variable of corporate governance has a contingent effect on the implementation of other governance elements, which further supports the relevant views in this field. While explaining that the executive committee of state-owned enterprise group has restraint effect on the individual will and ability of executives, it further reflects the effectiveness of executives' synergy allocation in private enterprise group. Compared with state-owned enterprise groups, private enterprise groups are more necessary to implement executives' synergy allocation, improve parent-subsidiary corporate governance mechanism, alleviate agency problems, and improve subsidiary corporate governance efficiency and quality.

\section{Research Limitations and Future Prospects}

First of all, due to the availability of relevant data and the time lag of disclosure, this paper only selects the data from 2014 to 2017. Future research can expand the sample size with the increase of information disclosure in relevant databases. Secondly, as the development momentum of enterprise groups in China continues to increase, future research can take enterprise groups as a sample to explore the differences in governance situations between parent and subsidiary companies in the context of enterprise groups and to understand the decision logic of green governance in a more comprehensive and in-depth manner.

\section{Acknowledgments}

The authors gratefully acknowledge the support from National Natural Science Foundation of China (grant no.71972117; 71602099) and the Taishan Scholars Program of Shandong Province (grant no. tsqn 202103095).

\section{Conflict of Interest}

The authors declare no conflict of interest.

\section{References}

1. FENG Y., CHEN H., CHEN Z., WANG W., WEI W. Has environmental information disclosure eased the economic inhibition of air pollution?. Journal of Cleaner Production. 284, 125412, 2021

2. LI W., XU J., ZHENG M. Green governance: New perspective from open innovation. Sustainability. 10 (11), 3845, 2018.
3. LI X., LI W., ZHANG Y. Family control, political connection, and corporate green governance. Sustainability. 12 (17), 7068, 2020.

4. WESTON B.H., BOLLIER D. Green governance: ecological survival, human rights, and the law of the commons. Journal of Law and Society. 40 (3), 468, 2013.

5. CAMILLERI M.A. Valuing stakeholder engagement and sustainability reporting. Corporate Reputation Review. 18 (3), 210, 2015

6. PLAZA-ÚBEDA J.A., DE BURGOS-JIMÉNEZ J., CARMONA-MORENO E. Measuring stakeholder integration: knowledge, interaction and adaptational behavior dimensions. Journal of Business Ethics. 93 (3), 419, 2010.

7. POST C., RAHMAN N., RUBOW E. Green governance: Boards of directors' composition and environmental corporate social responsibility. Business \& Society. 50 (1), 189, 2011.

8. CHELLI M., DUROCHER S., RICHARD J. France's new economic regulations: insights from institutional legitimacy theory. Accounting, Auditing \& Accountability Journal. 27 (2), 283, 2014

9. DEEGAN C., GORDON B. A study of the environmental disclosure practices of Australian corporations. Accounting and Business Research. 26 (3), 187, 1996.

10. TANG A.K.Y., LAI K., CHENG T.C.E. Environmental governance of enterprises and their economic upshot through corporate reputation and customer satisfaction. Business Strategy and the Environment. 21 (6), 401, 2012.

11. WANG S., WANG H., WANG J., YANG F. Does environmental information disclosure contribute to improve firm financial performance? An examination of the underlying mechanism. Science of the Total Environment. 714, 136855, 2020.

12. MENG X., ZENG S., XIE X., ZOU H. Beyond symbolic and substantive: Strategic disclosure of corporate environmental information in China. Business Strategy and the Environment. 28 (2), 403, 2019.

13. LI D., ZHAO Y., SUN Y., YIN D. Corporate environmental performance, environmental information disclosure, and financial performance: Evidence from China. Human and Ecological Risk Assessment: An International Journal. 23 (2), 323, 2017.

14. STEFANO F., EUGENIO D., DANIELA C., SILVIA S. Does environmental performance affect companies' environmental disclosure? Measuring Business Excellence. 19 (3), 42, 2015.

15. JAIN A., JAIN P.K., MCINISH T.H. Worldwide reach of short selling regulations. Journal of Financial Economics. 109 (1), 177, 2013.

16. LIU W., WEI Q., HUANG S.Q., TSAI, S.B. Doing good again? A multilevel institutional perspective on corporate environmental responsibility and philanthropic strategy. International Journal of Environmental Research and Public Health. 14 (10), 1283, 2017.

17. DU X., CHANG Y., ZENG Q., DU Y., PEI H. Corporate environmental responsibility (CER) weakness, media coverage, and corporate philanthropy: Evidence from China. Asia Pacific Journal of Management. 33 (2), 551, 2016.

18. LAGUIR I., STAGLIANÒ R., ELBAZ J. Does corporate social responsibility affect corporate tax aggressiveness?. Journal of Cleaner Production. 107, 662, 2015.

19. SHAUKAT A., QIU Y., TROJANOWSKI G. Board attributes, corporate social responsibility strategy, 
and corporate environmental and social performance. Journal of Business Ethics. 135 (3), 569, 2016.

20. HAMBRICK D.C., MASON P.A. Upper echelons: The organization as a reflection of its top managers. Academy of Management Review. 9 (2), 193, 1984.

21. TANG Y., MACK D.Z., CHEN G. The differential effects of CEO narcissism and hubris on corporate social responsibility. Strategic Management Journal. 39 (5), 1370, 2018.

22. JENSEN M.C., MECKLING W.H. Theory of the firm: Managerial behavior, agency costs and ownership structure. Journal of Financial Economics. 3 (4), 305, 1976.

23. LO F.Y. Factors leading to foreign subsidiary ownership: A multi-level perspective. Journal of Business Research. 69 (11), 5228, 2016.

24. CHEN J., EZZAMEL M., CAI Z. Managerial power theory, tournament theory, and executive pay in China. Journal of Corporate Finance. 17 (4), 1176, 2011.

25. JIANG G., LEE C.M., YUE H. Tunneling through intercorporate loans: The China experience. Journal of Financial Economics. 98 (1), 1, 2010.

26. LIU Q., LUO T., TIAN G.G. Family control and corporate cash holdings: Evidence from China[J]. Journal of Corporate Finance. 31, 220, 2015.

27. UDEKEM B. Agency Conflicts and Dividend Persistence. Journal of Financial Services Research. 1-28, 2021.

28. HAN P.F., HU Y.M., HE Y., WANG H.F. Research on the operation mechanism of enterprise groups: tunneling, relief or risk sharing. Management World. 34, 120, 2018.

29. BERTRAND M., MEHTA P., MULLAINATHAN S. Ferreting out tunneling: An application to Indian business groups. The Quarterly Journal of Economics. 117 (1), 121, 2002.

30. JIANG G., LEE C.M.C., YUE H. Tunneling through intercorporate loans: The China experience. Journal of Financial Economics. 98 (1), 1, 2010.

31. JIAN M., WONG T.J. Propping through related party transactions. Review of Accounting Studies. 15 (1), 70, 2010.

32. LI J., WANG L., ZHOU Z.Q., ZHANG Y.J. Monitoring or tunneling? Information interaction among large shareholders and the crash risk of the stock price. PacificBasin Finance Journal. 65, 101469, 2021.

33. DELANY E. Strategic development of the multinational subsidiary through subsidiary initiative-taking. Long Range Planning. 33 (2), 220, 2000.

34. RIZZO J.R., HOUSE R.J., LIRTZMAN S.I. Role conflict and ambiguity in complex organizations. Administrative Science Quarterly. 15 (2), 150, 1970.

35. BELIAS D., KOUSTELIOS A., SDROLIAS L., ASPRIDIS G. Job satisfaction, role conflict and autonomy of employees in the Greek banking organization. ProcediaSocial and Behavioral Sciences. 175, 324, 2015.

36. HUSSAIN S.T., LEI S. Role stressors and job satisfaction in the banking industry: The mediating role of job stress. International Business Research. 8 (9), 105, 2015.

37. KAWAI N., MOHR A. The contingent effects of role ambiguity and role novelty on expatriates' work-related outcomes. British Journal of Management. 26 (2), 163, 2015.

38. HILLMAN A.J., DALZIEL T. Boards of directors and firm performance: Integrating agency and resource dependence perspectives. Academy of Management Review. 28 (3), 383, 2003.

39. MAAS K. Do corporate social performance targets in executive compensation contribute to corporate social performance?. Journal of Business Ethics. 148 (3), 573, 2018.

40. FACCIO M., LANG L.H.P. The ultimate ownership of Western European corporations. Journal of Financial Economics. 65 (3), 365, 2002.

41. LÓPEZ-DE-FORONDA Ó., LÓPEZ-ITURRIAGA F.J., SANTAMARÍA-MARISCAL M. Ownership structure, sharing of control and legal framework: International evidence. Corporate Governance: An International Review. 15 (6), 1130, 2007.

42. SHAOJIA L., PEI S., NAIQUAN L. The Ultimate Ownership and Its Shareholding Structures: Does It Matter for Corporate Performance?. Economic Research Journal. 4, 51, 2003.

43. SHLEIFER A., VISHNY R.W. Large shareholders and corporate control. Journal of Political Economy. 94 (3), 461, 1986.

44. YU Y., LIU Y., BAI T. Does attention from headquarters influence subsidiary behavior? A social psychological perspective. Long Range Planning. 52 (4), 101877, 2019.

45. CONTRACTOR F., YANG Y., GAUR A.S. Firmspecific intangible assets and subsidiary profitability: The moderating role of distance, ownership strategy and subsidiary experience. Journal of World Business. 51 (6), 950, 2016.

46. LI X.H., LIANG X. A Confucian social model of political appointments among Chinese private-firm entrepreneurs. Academy of Management Journal. 58 (2), 592, 2015.

47. CHIN M.K., HAMBRICK D.C., TREVIÑO L.K. Political ideologies of CEOs: The influence of executives' values on corporate social responsibility. Administrative Science Quarterly. 58 (2), 197, 2013.

48. MENG X.H., ZENG S.X., SHI J.J., QI Z.Y., ZHANG Z.B. The relationship between corporate environmental performance and environmental disclosure: An empirical study in China. Journal of Environmental Management. 145, 357, 2014.

49. BRICKLEY J.A., COLES J.L., JARRELL G. Leadership structure: Separating the CEO and chairman of the board. Journal of corporate Finance. 3 (3), 189, 1997.

50. MIGDADI M.M, ZAID M.K.A, YOUSIF M, ALMESTARIHI, R.D., AL-HYARI, K. An empirical examination of knowledge management processes and market orientation, innovation capability, and organisational performance: Insights from Jordan. Journal of Information \& Knowledge Management. 16 (1), 1, 2017.

51. PENG M.W., LI Y., XIE E., SU Z. CEO duality, organizational slack, and firm performance in China. Asia Pacific Journal of Management. 27 (4), 611, 2010.

52. MARTIN J.A, BUTLER F.C. Agent and stewardship behavior: How do they differ?. Journal of Management \& Organization. 23 (5), 633, 2017.

53. FALEYE O. CEO directors, executive incentives, and corporate strategic initiatives. Journal of Financial Research. 34 (2), 241, 2011.

54. SHER P.J., YANG P.Y. The effects of innovative capabilities and $R \& D$ clustering on firm performance: the evidence of Taiwan's semiconductor industry. Technovation. 25 (1), 33, 2005.

55. FU T.W., KE M.C., HUANG Y.S. Capital growth, financing source and profitability of small businesses: evidence from Taiwan small enterprises. Small Business Economics. 18 (4), 257, 2002.

56. RASHID A. Managerial ownership and agency cost: evidence from Bangladesh. Journal of Business Ethics. 137 (3), 609, 2016. 
57. MERINO E., MANZANEQUE-LIZANO M., SANCHEZARAQUE J. Sustainability and Corporate Governance: Transparency and Excessive Directors' Remuneration in Listed Companies during the Global Financial Crisis. Sustainability. 12 (1), 158, 2020.

58. LEMMON M.L., LINS K.V. Ownership structure, corporate governance, and firm value: Evidence from the
East Asian financial crisis. The Journal of Finance. 58 (4), 1445, 2003.

59. CHEN G., FIRTH M., GAO D.N, RUI O.M. Ownership structure, corporate governance, and fraud: Evidence from China. Journal of Corporate Finance. 12 (3), 424, 2006. 